\title{
The Jet Stream Complex over the Pacific
}

\author{
By S. M. Serebreny and F. J. Wiegman \\ Pan American World Airways, San Francisco, U.S.A. \\ (Manuscript received 12 June 1957)
}

\begin{abstract}
The Jet Stream complex over the Pacific is comprised of multiple Jet Streams which form, intensify and weaken in differing manner depending upon the synoptic situation and area. Regicnal differences within the Pacific are discussed. The axis of seasonal "strong" winds is determined and compared to the mean position of the principal baroclinic zone. Multiple Jet Stream systems are related to multiple baroclinic zones and characteristic temperature ranges of these zones are delineated and compared to values given for North America. Specific thermal and contour height ranges at the $500 \mathrm{mb}$ level can be identified with each of the multiple Jet Stream systems. The distribution and incidence of "strong" wind velocities at the $500 \mathrm{mb}$ level with certain $500 \mathrm{mb}$ contour heights and temperatures is demonstrated for selected stations in the Pacific. Use of these thermal-contour height ranges as an aid in identification, location and forecasting of the Jet Stream complex is emphasized.
\end{abstract}

\section{Climatological considerations}

The Jet Stream complex over the Pacific is comprised of multiple jet streams which form, intensify and weaken in differing manner depending upon the synoptic situation and area. However, when these individual Jet Streams are averaged over long periods of time the fine structure is eliminated and a single Jet Stream results. During the winter season the mean position of this resultant Jet Stream in the Western Pacific is located between $30^{\circ} \mathrm{N}$ and $40^{\circ} \mathrm{N}$ latitude while in the Eastern Pacific the mean position is between $40^{\circ} \mathrm{N}$ and $50^{\circ} \mathrm{N}$ latitude. While knowledge of this resultant Jet Stream is both valuable and desirable, of more paramount importance is the realization that regional differences within the Pacific play a major role in the understanding of this resultant Jet Stream and, ultimately, the Jet Stream complex itself.

Physically, the Jet Streams in the Pacific are quite similar to those in other parts of the world i.e., the same relationships anent fronts, distribution of shear, etc. are valid. The principal difference lies in the degree of intensity and subsequent modification of air masses over the long expance of water. Since in the Pacific the principal air mass contrasts are maritime, any delineation of the Jet Stream complex must consider the regional climatology of the individual areas of the Pacific.

In the Western Pacific, confluence between the cold continental air masses from Siberia and warm maritime sources near Japan results in the presence of extreme thermal contrasts through relatively deep layers. This strong thermal contrast is further intensified by the barrier effect on the westerlies of the Himalayan Massif. This barrier causes the westerly flow to be deflected into separate streams on either side of it. Downstream from this barrier these separate streams are reunited into one broad band near the Japanese area and the far Western Pacific. Thus a mechanical convergence zone is superimposed on the normal air mass trajectory and, as a result, the Jet Stream in this area is one of the most widespread and intense observed anywhere in the world. The Jet Stream complex during winter 
usually consists of two or more Jet Streams. With the occurrence of a major trough in the Western Pacific they may merge and appear as one. However, they tend to diverge again downstream from the trough. During the winter months this region of separation usually occurs in the vicinity of $150^{\circ} \mathrm{E}$ to $170^{\circ} \mathrm{E}$.

In the Central and Eastern Pacific the Jet Stream complex in the rean during winter becomes diffuse which is a reflection of the great variability in the position of the Polar Front and the modification of air masses in this area. Near Hawaii a Jet Stream is sometimes found just to the south of the islands associated with high level cold vorticies while another Jet Stream, associated with the Polar Front, is found far to the north.

\section{Incidence of winds in excess of 75 knots over the Pacific during winter}

In order to emphasize the climatological reality of the Jet Stream complex a series of charts (Figs. 1 to 3 ) based on the in cidence of wind velocities in excess of 75 knots throughout the Facific for the winter at selected altitudes have been included. (8) (9).

Although these charts do not represent the Jet Streams directly, it is reasonable to assurre that the majority of occurrences of these high velocity winds are associated with them. In addition, the axis of incidence delineates, to some degree, the mean position of those Jet Streams which attained a 75 knot intensity at the selected levels.

The charts for 200, 300 and $500 \mathrm{mbs}$ (Figs. 1 to 3 ) illustrate, quite markedly, the occurrence and steadiness of wind velocities in excess of 75 knots in the Western Pacific, particularly in the Japanese Island area. On the $200 \mathrm{mb}$ chart (Fig. 1) note the rapid decrease in occurrence of these strong velo. cities south of $30^{\circ} \mathrm{N}$. Strong velocities ap. pear with less frequency in the Eastern Pacific, reflecting a weakening of Jet Streams in this area. In general Jet Streams

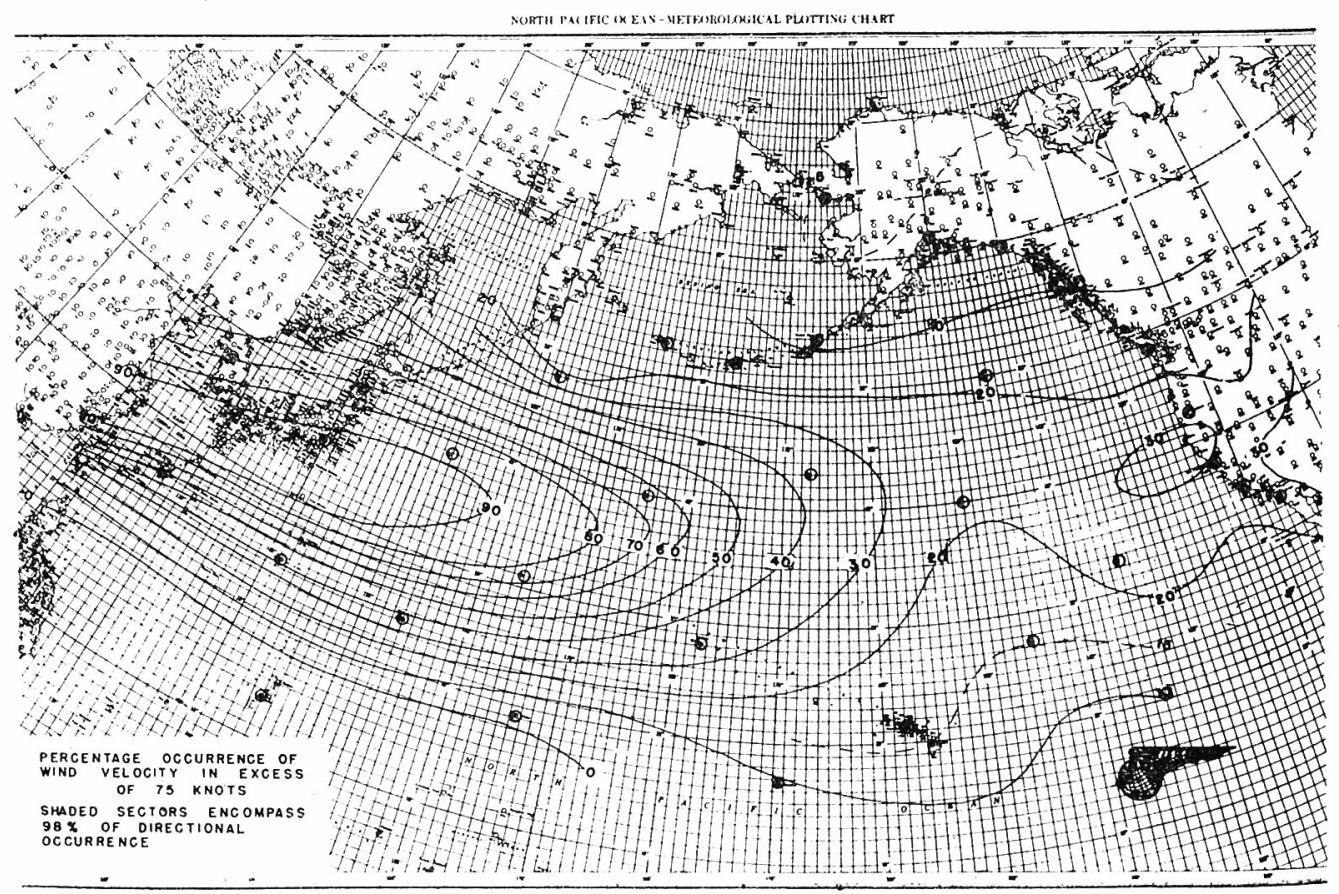

Fig. 1-Isopleths of Percentage Cccurrence of Wind Velccity in Excess of 75 knots at the $200 \mathrm{mb}$ Level in Winter. 
he in

of 75

winter luded.

resent ble to ces of ciated of in. mean tained vels.

(Figs.

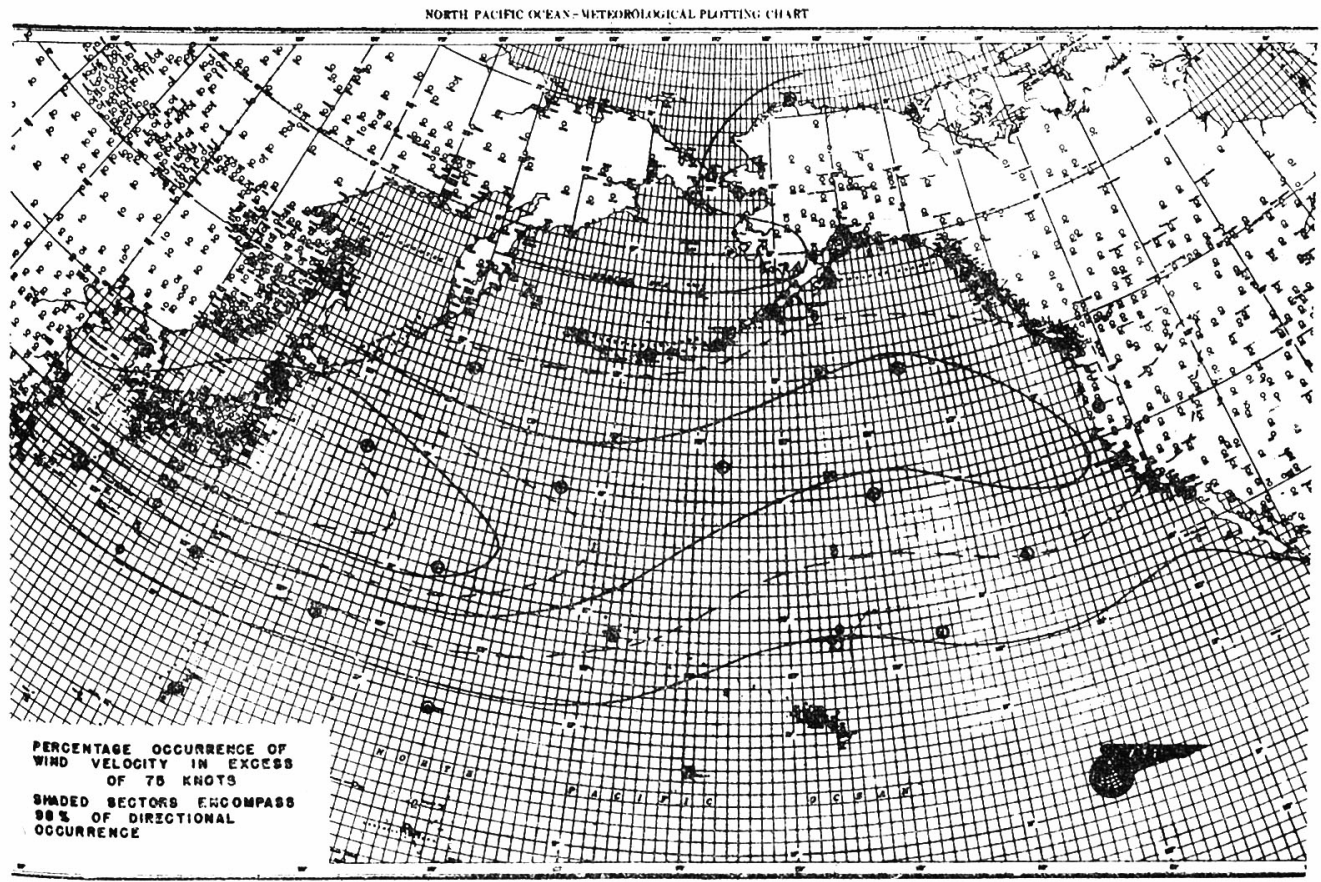

Fig. 3-Isopleths of Percentage Occurrence of Wind Velccity, in Excess of 75 knots at the $500 \mathrm{mb}$ Level in Winter. 
Streams in the Pacific area occur primarily in the vicinity of $40^{\circ} \mathrm{N}$ near the "normal" cyclone tracks. Strong velocities in the vicinity of the Hawaiian Islands reflect the appearance of intense high altitude cold lows.

The occurrence of strong winds at $300 \mathrm{mbs}$ (Fig. 2) is slightly less than at $200 \mathrm{mbs}$ in the Eastern Pacific. At $500 \mathrm{mbs}$ (Fig. 3 ) the incidence of 75 knot winds however, is greatly reduced, even in the Japanese area. Occurrence of the maximum incidence in the Japanese Islands is an illustration of the fact that the principal injection zone through which cold air is thrust into the Pacific is located in this area. Thus, the mean Jet Stream is most highly developed in this region. The decrease in incidence near the 150th W meridian reflects the frequent occurrence of high cells and ridges in this area which results in a weakening of the mean Jet Stream.

\section{Mean position of the principal baroclinic zone}

Since Figures 1 to 3 delineate the incidence of winds in excess of 75 knots over the Pacific it is of some interest to establish the relationship of the mean position of the major baroclinic zone to this pattern.

In April 1950 D.P. McIntyre of Canada (3) suggested the use of frequency polygons to delineate baroclinic zones in North America. He showed that the mean thermal distribution could be studied through the use of histograms of temperatures at selected levels.

In essence histograms for stations that are consistently under the influence of a single air mass will be characterized by a strong central tendency maximum. Those stations consistently under the influence of a "front", however, will exhibit histograms characterized by two distinct temperature frequency maximum; the baroclinic field of the front being represented by the temperature range between these two ma- xima. In addition, if the baroclinic field is sloping, the "warm" portion of the thermal spectrum will increase with in creased altitude at the expense of the " cold" area.

To inspect the baroclinicity in the Pacific Ocean area we constructed similar histograms at stations for which ample data was available. These histograms were constructed from the data of the winter months, (January, February and March 1953) utilizing a class interval of $2^{\circ} \mathrm{C}$. The stations chosen are along, or near, three meridians $\left(140^{\circ} \mathrm{E}\right.$ longitude, $165^{\circ} \mathrm{E}$ longitude, $170^{\circ} \mathrm{W}$ longitude) and the West Coast of the United States.

The histograms along, or near, the $140^{\circ} \mathrm{E}$ meridian are for the following stations; Wakkanai, Sapporo, Misawa, Sendai, Tokyo, Shionomisaki in Japan and OSV Tango $\left(29^{\circ} \mathrm{N} 135^{\circ} \mathrm{E}\right)$ and Iwo Jima. (Figs. 4 and 5). Along this meridian $\left(140^{\circ} \mathrm{E}\right)$ the afore. mentioned criteria for pronounced baro. clinicity is most clearly evident at Tokyo (671), $\left(-2^{\circ} \mathrm{C}\right.$ to $-10^{\circ} \mathrm{C}$ at the $700 \mathrm{mb}$ level and $-18^{\circ} \mathrm{C}$ to $-28^{\circ} \mathrm{C}$ at the $500 \mathrm{mb}$ level). Thus the mean position of the principal baroclinic zone can be taken as being near Tokyo. The histograms north of Tokyo and south of OSV Tango exhibit characteristics of areas quite apart from the baroclinic field. It is interesting to note the rather peaked central tendency and the rather restricted total range of temperatures in the warm air over OSV Tango and Iwo Jima as distinguished from the less pronounced central tendency but wider range in the cold air at stations north of Tokyo. The distribution at the stations north of Tokyo illustrate the greater range of thermal differences that are inherent in cold air masses as compared to warm air masses.

Downstream from Japan we consider the stations near the $165^{\circ} \mathrm{E}$ meridianspecifically, OSV Sugar, OSV Extra, OSV Victor and Marcus Island, (Fig. 6). Here again the criteria for a sloping baroclinic 


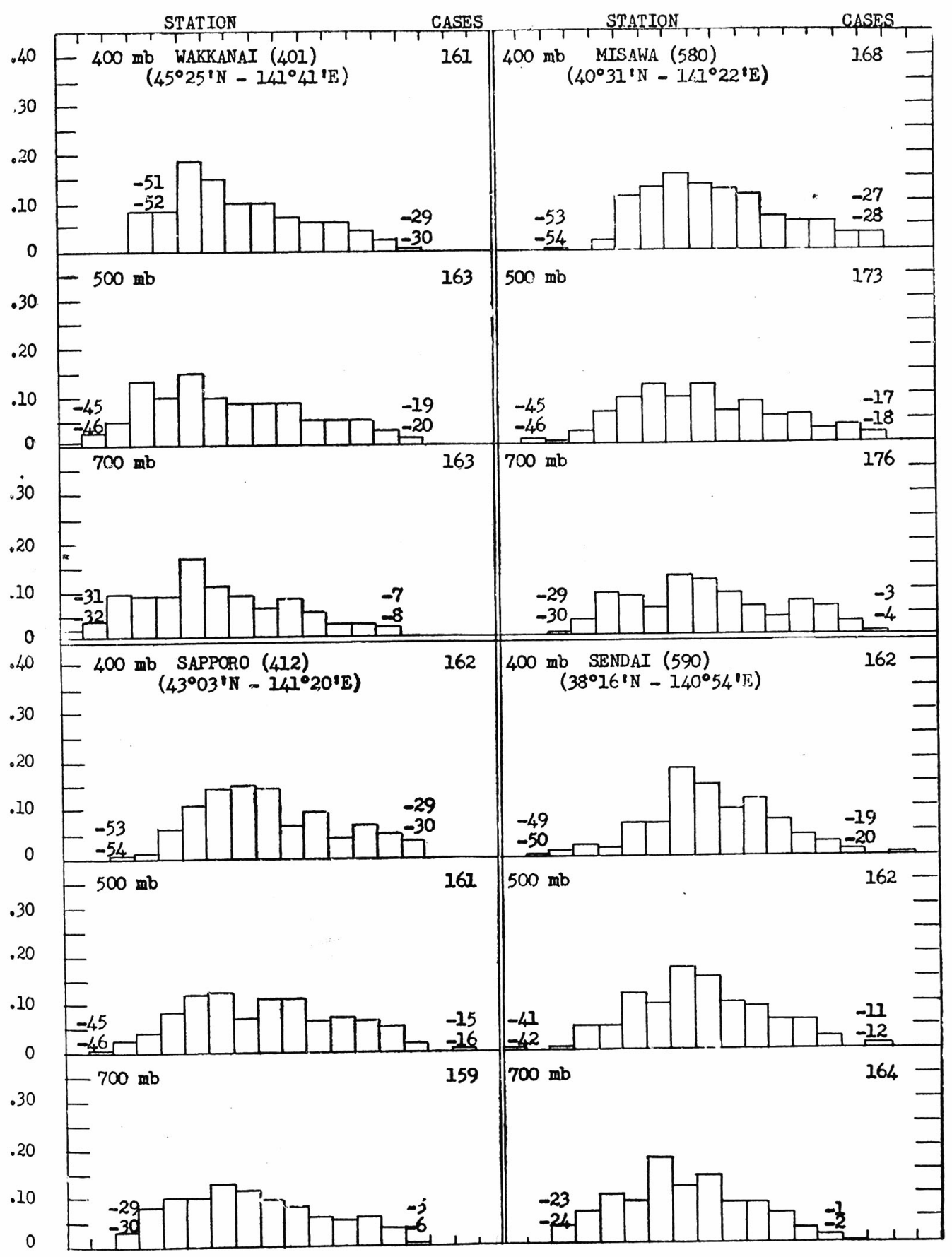

Fig. 4-Histograms of Temperature $\left({ }^{\circ} \mathrm{C}\right)$ at Selected Stations for January, February and March, 1953. 


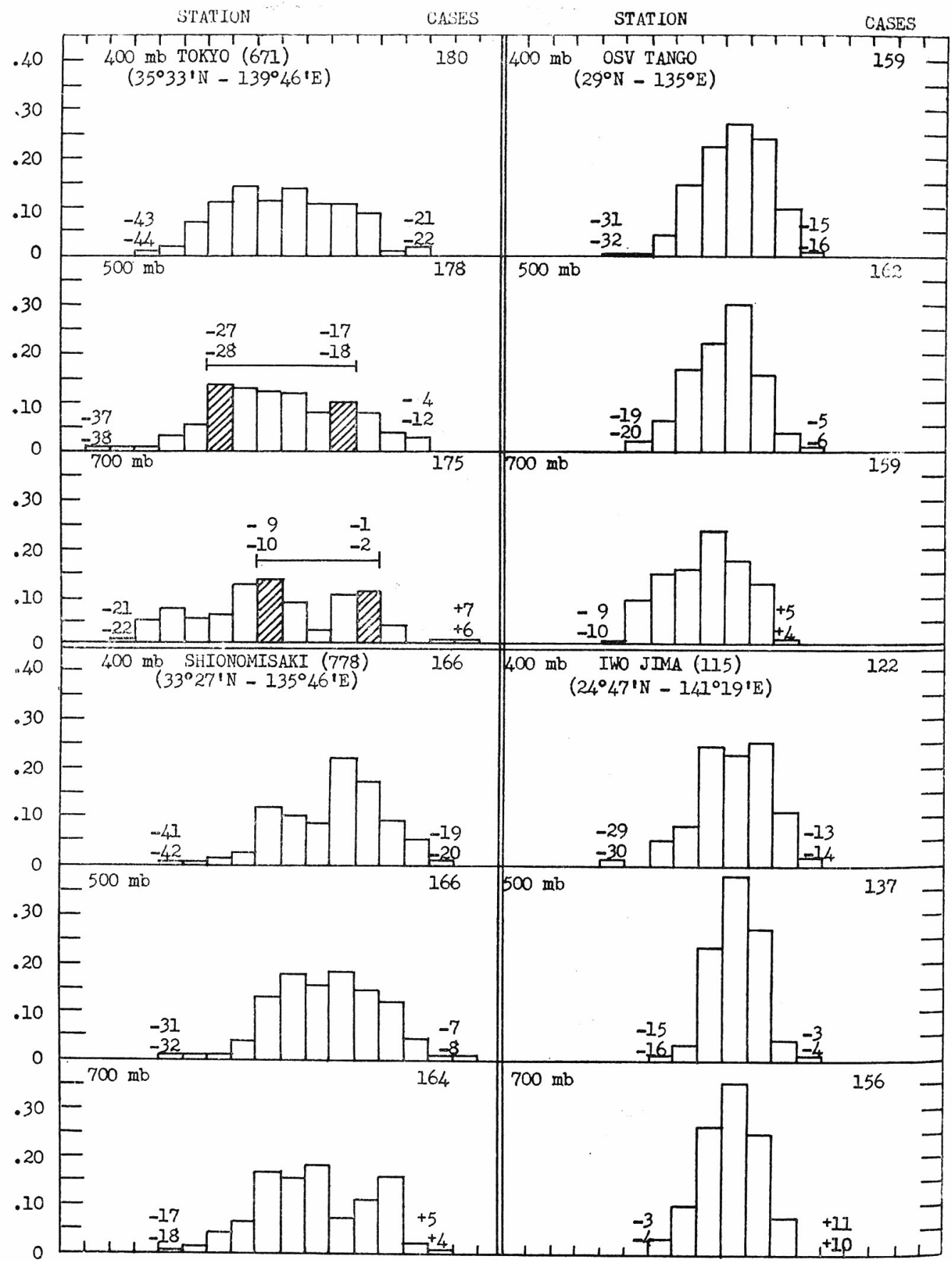

Fig. 5-Histograms of Temperature $\left({ }^{\circ} \mathrm{C}\right)$ at Selected Stations for January, February and March, 1953. 
The Jet Stream Complex over the Pacific

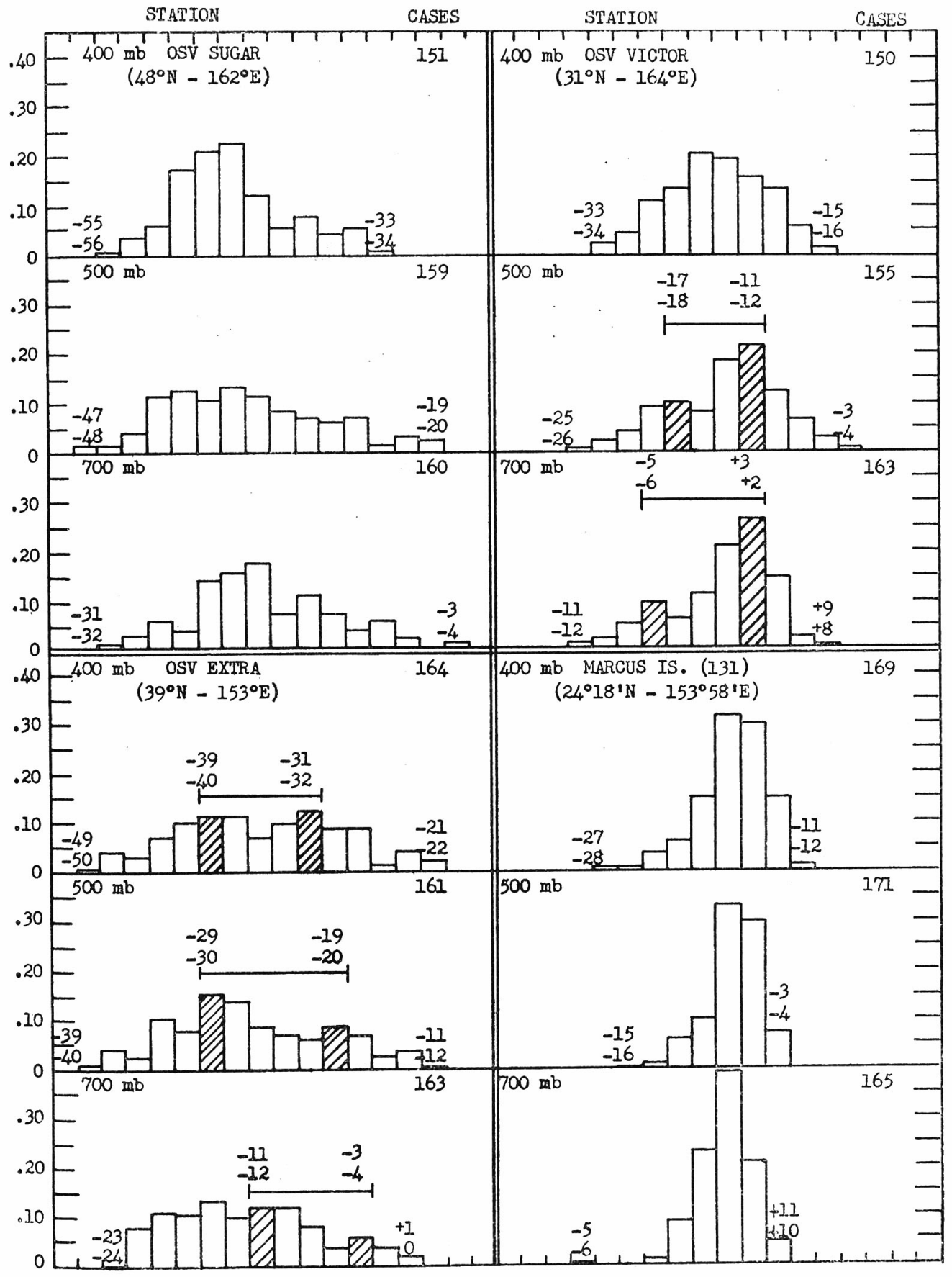

Fig. 6-Histograms of Temperature $\left({ }^{\circ} \mathrm{C}\right)$ at Selected Stations for January, February and March, 1953.

$-205-$ 


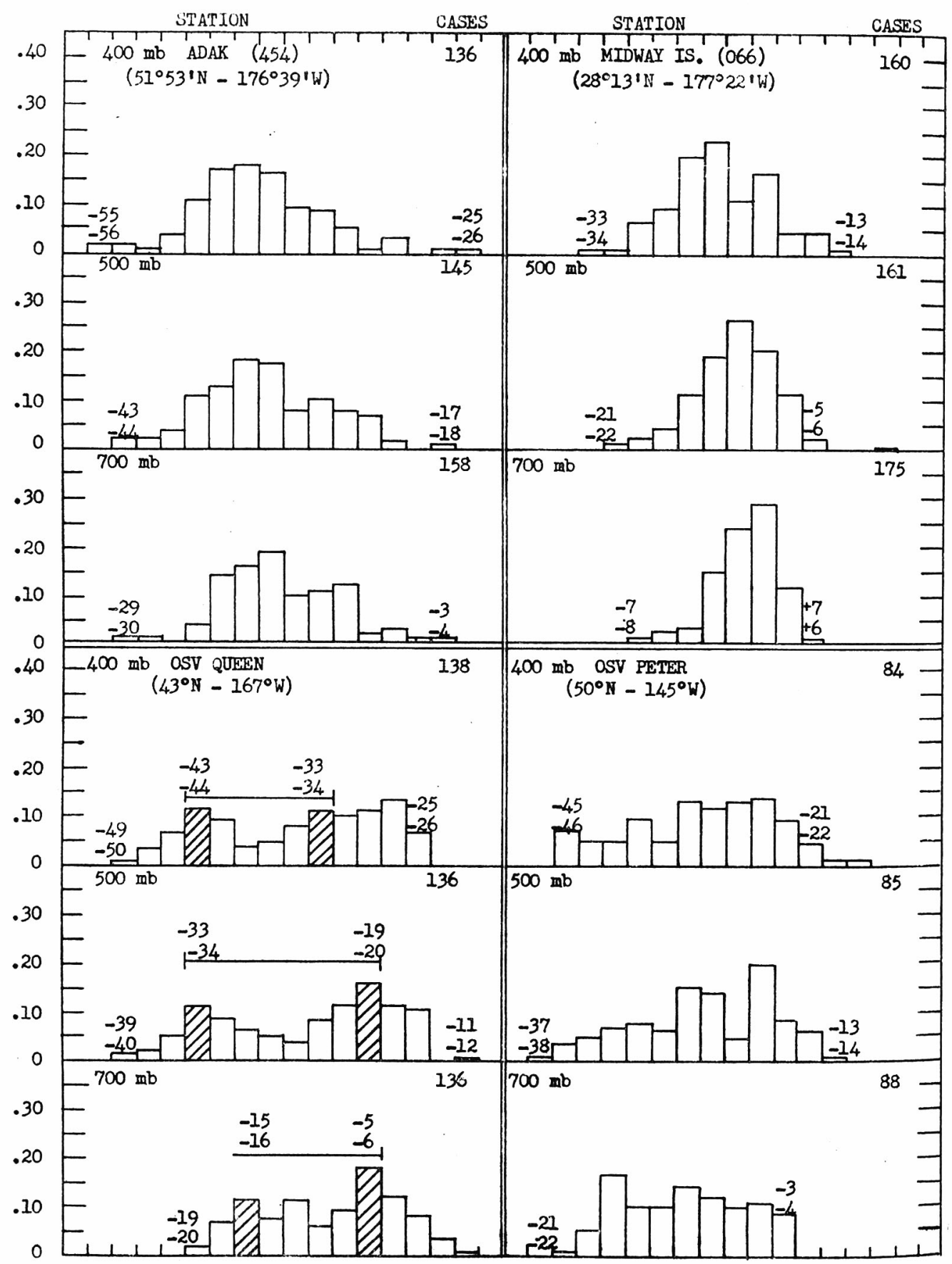

Fig. 7-Histograms of Temperature $\left({ }^{\circ} \mathrm{C}\right)$ at Selected Stations for January,

February and March, 1953. 
field is most clearly evident at OSV Extra and is represented by the thermal range of $-4^{\circ} \mathrm{C}$ to $-12^{\circ} \mathrm{C}$ at $700 \mathrm{mbs},-20^{\circ} \mathrm{C}$ to $-30^{\circ} \mathrm{C}$ at $500 \mathrm{mbs}$ and $-32^{\circ} \mathrm{C}$ to $-40^{\circ} \mathrm{C}$ at $400 \mathrm{mbs}$. A second baroclinic zone is found at OSV Victor, with temperatures ranging from $-12^{\circ} \mathrm{C}$ to $-18^{\circ} \mathrm{C}$ at $500 \mathrm{mbs}$, reflecting the occurence of old polar fronts in this area. This zone is rather shallow since there is no further evidence of it at the $400 \mathrm{mb}$ level.

Along the $170^{\circ} \mathrm{W}$ meridian (Fig. 7) the stations used are Adak, OSV Queen and Midway Island. The principal baroclinic zone is found over OSV Queen. At this station the baroclinic zone is defined by the ranges $-6^{\circ} \mathrm{C}$ to $-16^{\circ} \mathrm{C}$ at $700 \mathrm{mbs},-20^{\circ} \mathrm{C}$ to $-34^{\circ} \mathrm{C}$ at $500 \mathrm{mbs}$ and $-34^{\circ} \mathrm{C}$ to $-44^{\circ} \mathrm{C}$ at $400 \mathrm{mbs}$.

The study by McIntyre (3). places the mean baroclinic zone along the West Coast of the United States near Tatoosh Island. It is marked by the thermal ranges $-2.5^{\circ} \mathrm{C}$ to $-14.5^{\circ} \mathrm{C},-21.5^{\circ} \mathrm{C}$ to $-31.5^{\circ} \mathrm{C},-35.5^{\circ} \mathrm{C}$ to $-43.5^{\circ} \mathrm{C}$ at 700,500 and $400 \mathrm{mb}$ levels respectively.

Thus, in summation, the mean position of the principal baroclinic zone over the Pacific in the winter of 1953 is found near Tokyo, OSV Extra, OSV Queen and Tatoosh Island. It is characterized by an average thermal range of $-3^{\circ} \mathrm{C}$ to $-13^{\circ} \mathrm{C},-20^{\circ} \mathrm{C}$ to $-30^{\circ} \mathrm{C}$ and $-34^{\circ} \mathrm{C}$ to $-42^{\circ} \mathrm{C}$ at the 700,500 and $400 \mathrm{mb}$ levels, respectively.

It is important to point out that the mean condition used to delineate the general circulation is merely the result of the myriads of trajectories and wind flows averaged for relatively long periods of time. As a result of this distillation only those flow patterns that exhibit the most frequent occurrence and the least variability remain. While the knowledge of these mean circulation patterns is most useful, too much emphasis must not be placed upon mean charts. The meteorologist must consider the range of daily patterns that may go into the composition of the mean chartthose patterns that occur with relative infrequency as well as the predominant ones.

\section{Synoptic considerations: Frontal zones and associated Jet Streams}

While the foregoing portrays conditions charactaristic of the principal baroclinic zone in the Pacific, synoptic experience, however, shows that on any one day more than one baroclinic zone is observed. The multiple Jet Stream systems that exist are reflected in the presence of these multiple baroclinic zones which would be evident were more data available.

Criteria for temperature characteristics of the air masses in Canada and the United States comprising the various frontal systems (baroclinic zones) have been given by members of the Canadian Weather Service (1, 2 and 5) and are shown in Table I.

\begin{tabular}{|c|c|c|c|c|}
\hline $\mathrm{P}(\mathrm{mb})$ & $\begin{array}{c}\text { Ccntinental } \\
\text { Arctic }\end{array}$ & $\begin{array}{c}\text { Maritime } \\
\text { Arctic }\end{array}$ & $\begin{array}{c}\text { Maritime } \\
\text { Polar }\end{array}$ & $\begin{array}{c}\text { Maritime } \\
\text { Tropical }\end{array}$ \\
\hline $\begin{array}{l}300 \\
400 \\
500 \\
700\end{array}$ & $\begin{array}{l}-45^{\circ} \mathrm{C} \\
-46 \\
-40 \\
-25\end{array}$ & $\begin{array}{l}-50^{\circ} \mathrm{C} \\
-48 \\
-36 \\
-16\end{array}$ & $\begin{array}{l}-53^{\circ} \mathrm{C} \\
-36 \\
-23 \\
-3\end{array}$ & $\begin{array}{l}-42^{\circ} \mathrm{C} \\
-27 \\
-15 \\
+4\end{array}$ \\
\hline
\end{tabular}

These temperature ranges can also be found in the Pacific (with minor modifications due to regional differences. The baroclinic zones and their attendant Jet Stream regimes have also been studied ( 7 \& 8) and can be identified as follows:

a) The Arctic Front Jet Stream: associated with the thermal discontinuity between the Arctic air masses and Polar Continental air mass from Siberia. Over oceanic areas this latter air mass modified to a Maritime Arctic air mass. This Jet Stream is usually confined to latitudes north of $50^{\circ} \mathrm{N}$ except in the vicinity of the Japanese Islands where it may merge with the Interpolar Jet Stream in the troughs of the deep cold lows accompanying extensive cold outbreaks. A merger may re-occur in the Eastern Pacific in the vicinity of the Gulf of Alaska and 
the Northwest Coast of the United States during periods of intense meridional flow. As a rule this Jet Stream is quite segmented and localized at the $500 \mathrm{mb}$ level.

b) The Inter-Polar or Maritime Arctic Front Jet Stream-associated with the discontinuity between Polar Continental or Maritime Arctic on the cold side and the Maritime Polar Air masses on the warm side of the baroclinic zone. The precise thermal regime depends on the degree of modification of the MP air. This is the most intense and extensive of the Jet Streams. While other Jet Stream regimes usually exist in intense form only in local areas, the Inter-Polar Front Jet Stream can, and on most occasions does, extend across the Pacific Ocean into the continent of North America. The mean major boroclinic zone in the Pacific, as derived in the previous section, is associated primarily with this Jet Stream.

c) The Polar Front Jet Stream-associated with the air mass discontinuity between Maritime Polar air to the north and Maritime Tropical air to the south. It, too, may be extensive and intense, particularly in zonal flow.

The characteristic temperatures of the air masses involved in the Jet Stream complex in the Pacific are given in Table II. highest drops A de given extrem $\left(-50^{\circ} \mathrm{C}\right.$ Midwa delinea racteris stated, present (The tl represe MP ai high ve betwee south o bounda: Latitude Longitude Time Altitude Temperatur

$-36^{\circ} \mathrm{C}$
$-36^{\circ} \mathrm{C}$
$-36^{\circ} \mathrm{C}$
$-35^{\circ} \mathrm{C}$
$-31^{\circ} \mathrm{C}$
$-19^{\circ} \mathrm{C}$
$-24^{\circ} \mathrm{C}$
$-23^{\circ} \mathrm{C}$

Wind Directio
and Velocity
(Knots)
$265-106$
$275-125$
$275-122$
$285-115$
$280-120$
$275-132$
$255-125$
$270-70$

D-Values $-720 \mathrm{Ft}$. $-580 \mathrm{Ft}$. $-410 \mathrm{Ft}$. $\mathrm{M}$ $-5 \mathrm{Ft}$. $\mathrm{M}$ $+930 \mathrm{Ft}$ $+1320 \mathrm{Ft}$. readily recognizable when enough data at hand. An example of such a bro strong wind field due to the near merger of the Inter-Polar and Polar Front Jet Stream is seen in flight log of PAA Trip 824/03; (see Table III and Fig. 8).

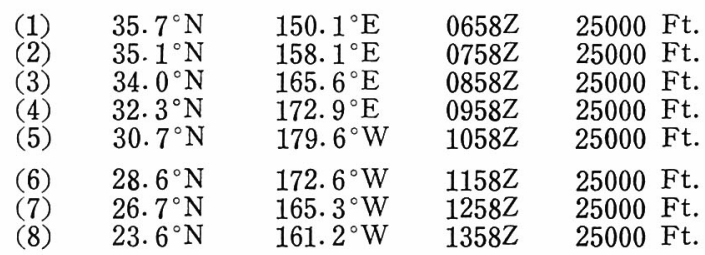

The airplane transited a high velocity wind field from $35.7^{\circ} \mathrm{N} ; 12$ degrees of latitude (720 miles) with winds in excess of 100 knots at all but the last report. Note the two velocity maximums at $0758 \mathrm{Z}$ with a temperature of $-36^{\circ} \mathrm{C}$ and at $1158 \mathrm{Z}$ with a temperature of $-19^{\circ} \mathrm{C}$. (This latter value is correct-even though the flight log reports are given in hourly increments here the readings are taken every ten minutes and there was a constant progression of temperature from $-31^{\circ} \mathrm{C}$ to $-19^{\circ} \mathrm{C}$ and again back to $-24^{\circ} \mathrm{C}$. A note from the pilot at $1150 Z$ states-"Warm air coincides with 
cross

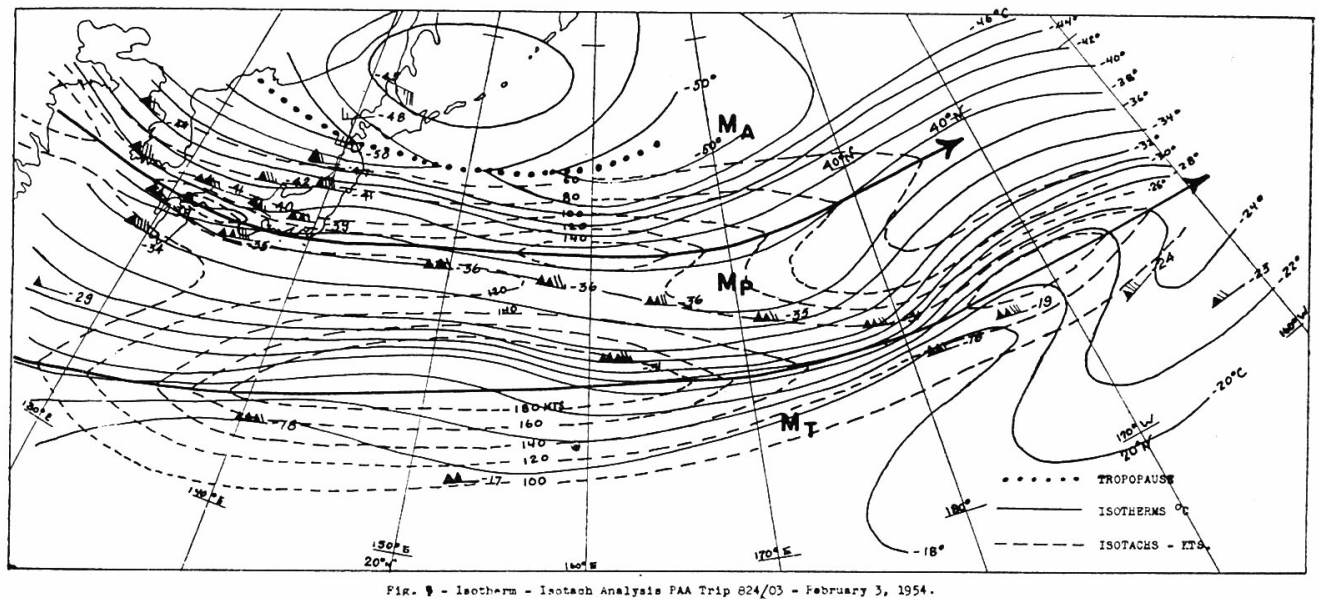

Fig. 8-Isotach-Isotherm Analysis for PAA Trip 824/03, February 3, 1954. highest wind of trip. Note temperature drops again as we go further south.”)

A delineation of the two wind fields is given in Fig. 8. It is evident from the extreme range of temperatures involved $\left(-50^{\circ} \mathrm{C}\right.$ in Northern Japan to $-16^{\circ} \mathrm{C}$ at Midway) that more than two air mass delineations are possible. Utilizing the characteristic air mass temperatures previously stated, it appears that Maritime Arctic air is present to the north of the aircraft track. (The thermal zone $-47^{\circ} \mathrm{C}$ to $-41^{\circ} \mathrm{C}$ in Japan represents the boundary between $\mathrm{MA}$ and MP air). Thus the aircraft experiences high velocity winds from the Jet Stream between these air masses even though it is south of the actual core. A second thermal boundary is observed further south separat- ing $\mathrm{MP}$ and $\mathrm{MT}$ air masses $\left(-31^{\circ} \mathrm{C}\right.$ to -19 ${ }^{\circ} \mathrm{C}$ ); the aircraft upon transiting this thermal boundary and its accompanying Jet Stream reported its highest wind velocity (130 knots). Note the strong winds at OSV Victor and Iwo Jima, (175 and 160 knots respectively) On the following day these streams merged in the vicinity of OSV Victor $\left(31^{\circ} \mathrm{N} 164^{\circ} \mathrm{E}\right)$ and a single very intense Jet Stream wind field resulted. Usually, however, both the Inter-Polar Front Jet Stream and the Polar Front Jet Stream exist independently.

In contrast, the flight reports of $\mathrm{PAA}$ Trip 822/10, February 10, 1953 (6) as given in Table IV illustrates the case of a marked narrow baroclinic zone (Polar Front) between MPW and MT air.

\section{Table IV-Flight Log PAA Tr

$\begin{array}{lcc}\text { Trip } & \text { Time } & \text { Position } \\ 82210 & 2010 \mathrm{Z} & 31.8^{\circ} \mathrm{N} / 170^{\circ} \mathrm{E} \\ & 2050 \mathrm{Z} & 31.4^{\circ} \mathrm{N} / 175^{\circ} \mathrm{E}\end{array}$ \\ Note the increase in wind of 55 knots in 24 miles of latitude accompanying this in- tense temperature change. \\ 5. Relation of strong winds to thermal regimes}

Our experience in the Pacific indicates that there is (a) an association of specific temperatures with strong winds, and (b)

$\begin{array}{ccc}\text { Altitude } & \text { Temperature } & \text { Wind } \\ 21,700^{\prime} & -28^{\circ} \mathrm{C} & 270^{\circ} / 105 \text { knots } \\ 21,800^{\prime} & -17^{\circ} \mathrm{C} & 260^{\circ} / 160 \text { knots }\end{array}$

that strong wind regimes tend to occur within selected height ranges in combination with these temperatures. (8)

Figs. 9 to 15 illustrate these relationships between Jet Stream winds, temperatures and constant pressure heights at $500 \mathrm{mbs}$.

Fig. 9-Sapporo $\left(43^{\circ} 03^{\prime} \mathrm{N}-141^{\circ} 20^{\prime} \mathrm{E}\right)$ :

Sample-267 cases (9 winter months) Approximately $20 \%$ of the cases have velo- 


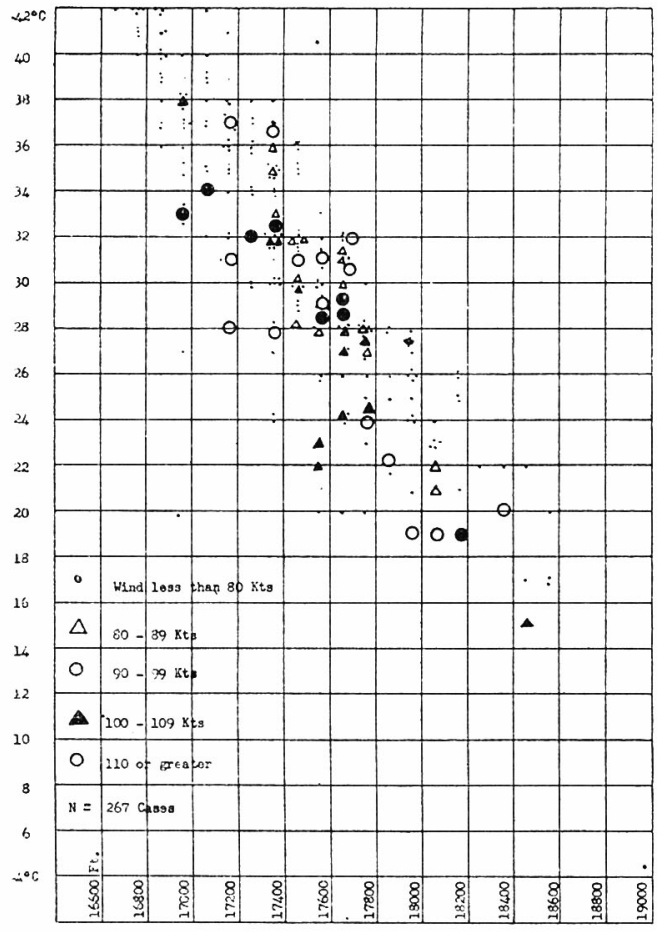

Fig. 9-Distribution of Velccities, Temperatures and $500 \mathrm{mb}$ Heights at Sapporo (412) $\left(43^{\circ} 03^{\prime} \mathrm{N} 140^{\circ} 20^{\prime} \mathrm{E}\right)$ during 9 Winter Months.

cities in excess of 80 knots with a maximum of 135 knots. Of these strong velocities $70 \%$ of the cases occur within the height range 17,300 to 17,800 feet. Two distinct temperature concentrations within the distribution of strong velocities are apparent; $-18^{\circ} \mathrm{C}$ to $-24^{\circ} \mathrm{C}$ and $-27^{\circ} \mathrm{C}$ to $-34^{\circ} \mathrm{C}$ (associated with the warm side of the Arctic Front) with the latter having the greater incidence.

Fig. $10-$ Tateno $\left(35^{\circ}\left(3^{\prime} \mathrm{N}-140^{\circ} 08^{\prime} \mathrm{E}\right)\right.$ :

Sample-270 cases (9 winter months). At this station approximately $40 \%$ of the cases show winds in excess of 80 knots while only $16 \%$ are less than 50 knots. These valus, plus the fact that approximately 13 $\%$ of the cases are in excess of 100 knots, show that a Jet Stream is in close proximity to this station at nearly all times during the winter months. With respect to contour heights, $54 \%$ of all winds occur in the

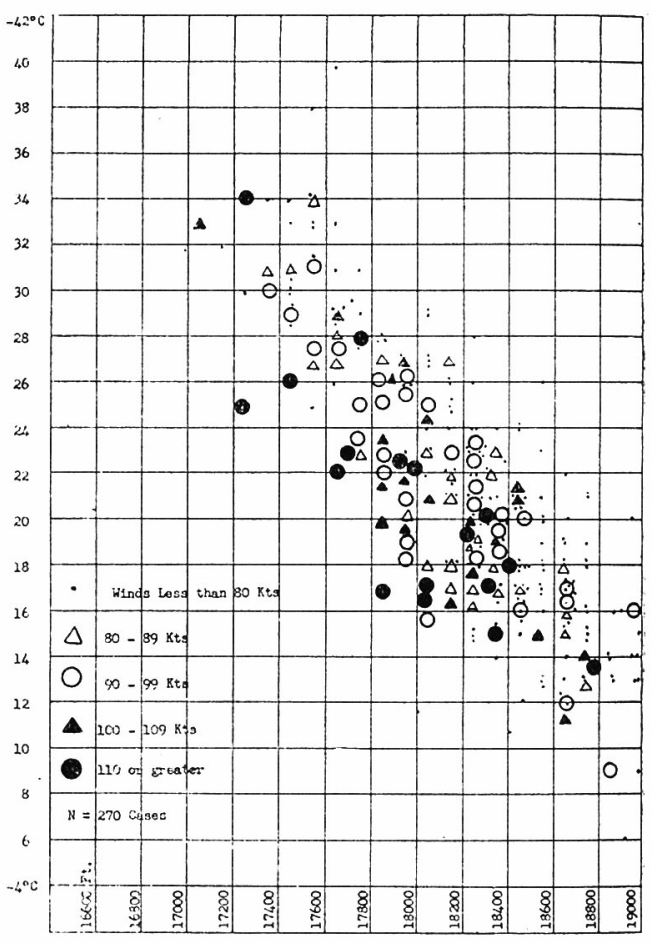

Fig. 10-Distribution of Velccities, Temperatures and $500 \mathrm{mb}$ Heights at Tateno (646) $\left(35^{\circ} 03^{\prime} \mathrm{N} 140^{\circ} 08^{\prime} \mathrm{E}\right)$ during 9 Winter Months.

range 17,800 to 18,500 feet. The maximum incidence of strong wind velocities occur within the height range 17,800 to 18,400 feet and the temperature range $-16^{\circ} \mathrm{C}$ to $-26^{\circ} \mathrm{C}$ (Inter-Polar Front). There is a sharp drop in the incidence of strong winds with temperatures colder than $-27^{\circ} \mathrm{C}$. Moderate to light wind velocities are prevalent with contour heights in excess of 18, 400 feet. The strongest velocities at 500 mbs usually occur with the combination of warm temperatures (i.e., warmer than $-18^{\circ} \mathrm{C}$ ) and low height values (less than 18,200 feet).

Fig. 11-OSV Sugar $\left(48^{\circ} \mathrm{N}-162^{\circ} \mathrm{E}\right)$ :

Sample-341 cases (14 winter months). The distribution at this station is quite similar to that at Sapporo although with a lesser frequency of strong winds since OSV Sugar is approximately five degrees further north in latitude. Only $10 \%$ of the wind velocities are in high i ing co major the he distin these $\left(-18^{\circ}\right.$ of ter Arctic respec The Sugar veloci and occurr peratu with v values quite Jet St. loped 


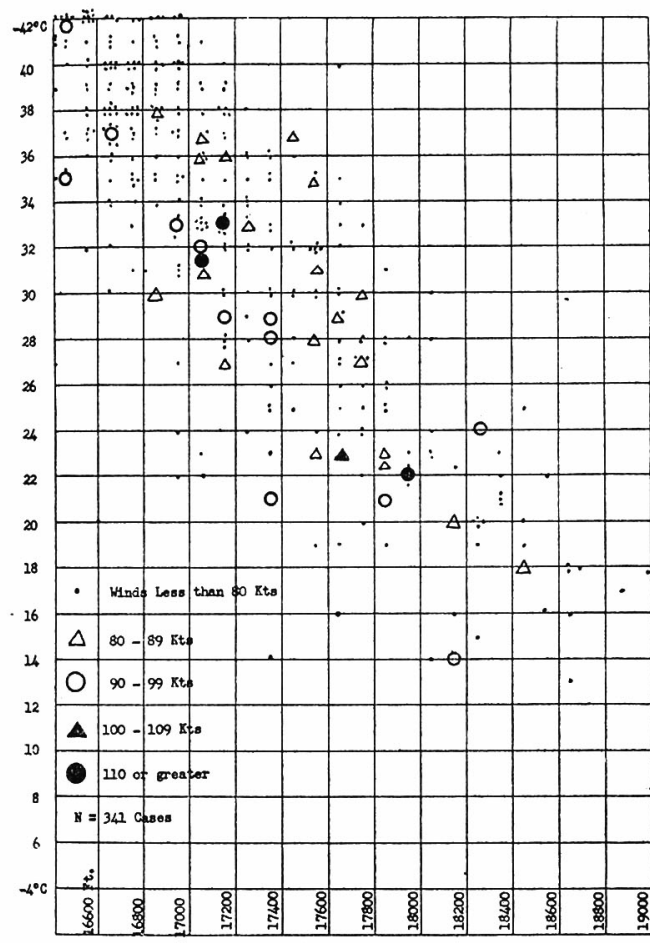

Fig. 11-Distribution of Velccities, Temperatures and $500 \mathrm{mb}$ Heights at OSV Sugar $\left(48^{\circ} \mathrm{N}\right.$ $162^{\circ} \mathrm{E}$ ) during 14 Winter Months.

are in excess of 80 knots with the very high incidence of weak velocities accompanying contour heights below 17,300 feet. The majority of strong winds are found within the height range 17,000 to 18,000 feet. Two distinct temperature clusters are noted for these strong winds $\left(-27^{\circ} \mathrm{C}\right.$ to $\left.-38^{\circ} \mathrm{C}\right)$ and $\left(-18^{\circ} \mathrm{C}\right.$ to $\left.-23^{\circ} \mathrm{C}\right)$ which are in the range of temperatures on the warm side of the Arctic Front and the Inter-polar Front, respectively.

The Jet Stream is mostly south of OSV Sugar during winter (high incidence of weak velocity winds with low contour heights and cold temperatures). Further, the occurrence of strong winds with cold temperatures and low height values as well as with warm temperatures and high height values suggests that the Jet Stream appears quite often at this station as a meridional Jet Stream in association with well-developed in-phase troughs and ridges.

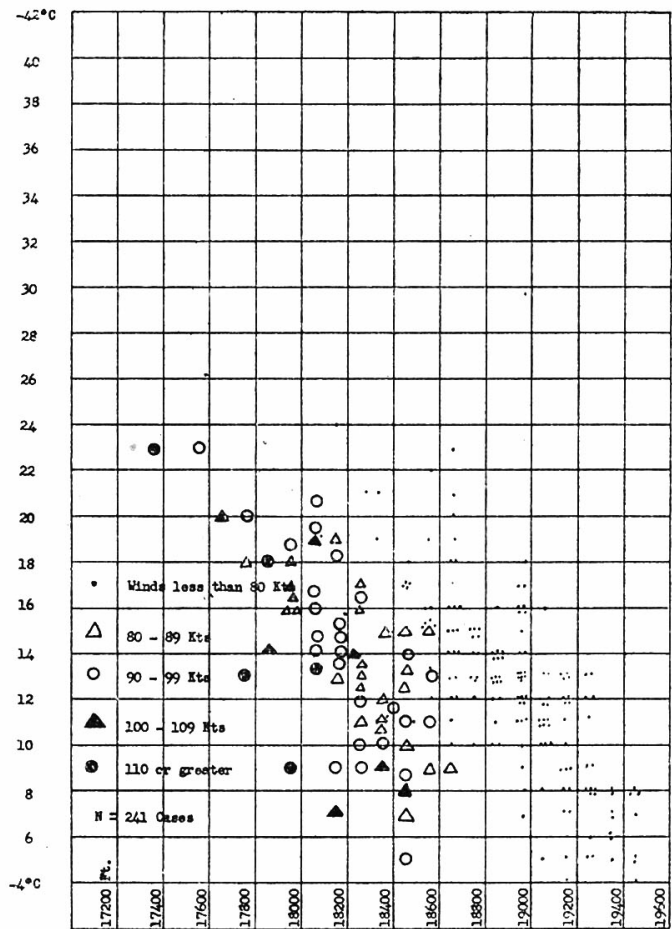

Fig. 12-Distribution of Velocities, Temperatures and $500 \mathrm{mb}$ Heights at OSV Victer $\left(31^{\circ} \mathrm{N}\right.$ $164^{\circ} \mathrm{E}$ ) during 9 Winter Months.

Fig. 12-OSV Victor $\left(31^{\circ} \mathrm{N}-164^{\circ} \mathrm{E}\right)$ : Sample -241 cases ( 9 winter months). The distribution is notable for the separation of strong winds and weak winds solely by contour values, the temperature range being nearly the same in both instances. Weak wind velocities are prevalent with contour heights above 19,000 feet, progressing from moderate velocities (90-99 knots) to strong velocities (in excess of 100 knots) in the height range from 17,800 feet to 18,400 feet. While moderate to strong velocities occur within the range from 17,700 feet to 19,000 feet the strongest winds occur with low to moderate contour heights and in the thermal range $-9^{\circ} \mathrm{C}$ to $-19^{\circ} \mathrm{C}$ (Polar Front).

Fig. 13-OSV Queen $\left(43^{\circ} \mathrm{N}-167^{\circ} \mathrm{W}\right)$ :

Sample-113 cases (4 winter months). The distribution shows that strong velocities occur within the height range 17,000 to 18,200 feet. There is a tendency for clustering, however, with respect to both 


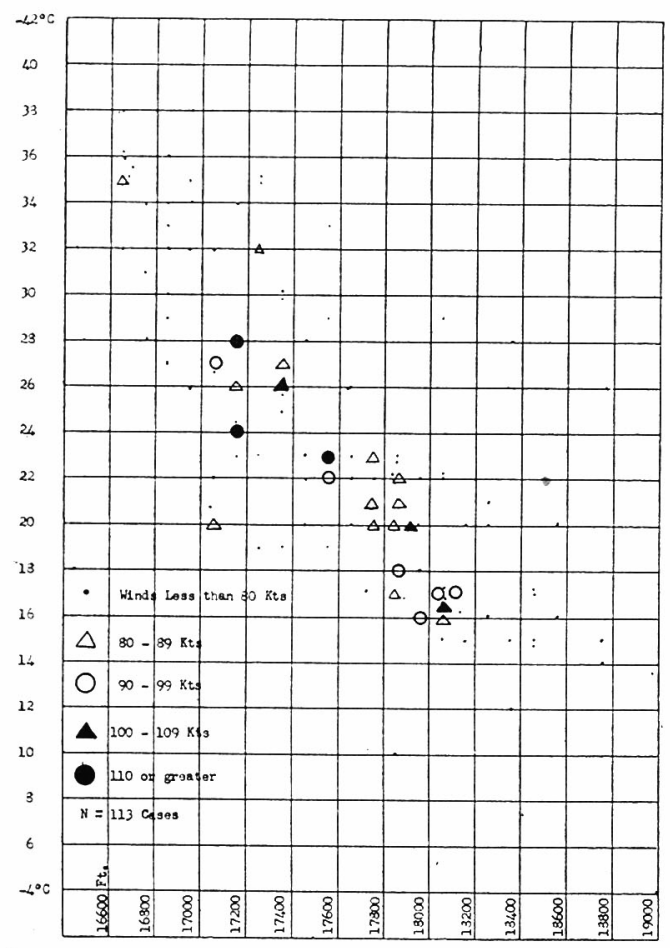

Fig. 13-Distribution of Velocities, Temperatures and $500 \mathrm{mb}$ Heights at OSV Queen $\left(43^{\circ} \mathrm{N}\right.$ $167^{\circ} \mathrm{W}$ ) during 4 Winter Months.

height and temperature; one group of strong velocities occurring in the height range 17,800 to 18,100 feet, temperature range $-16^{\circ} \mathrm{C}$ to $-23^{\circ} \mathrm{C}$ (warm side of the InterPolar Front); and another in the height range 17,000 feet to 17,400 feet, temperature range $-24^{\circ} \mathrm{C}$ to $-28^{\circ} \mathrm{C}$, (warm side of a merged broad Inter-Polar Front).

While the sample is somewhat limited, it is apparent that the Inter-polar Front Jet Stream oscillates over the station. Strong wind velocities occur through a moderate range of height and temperature values with no strong preference for any particular combination of height and temperature.

Fig. 14-Midway $\left(28^{\circ} 13^{\prime} \mathrm{N}-177^{\circ} 22^{\prime} \mathrm{W}\right)$ :

Sample-487 cases (20 winter months) The distribution is somewhat similar to that at OSV Victor insofar as there is a distinct tendency for strong wind velocities to cluster by contour heights rather than tempera-

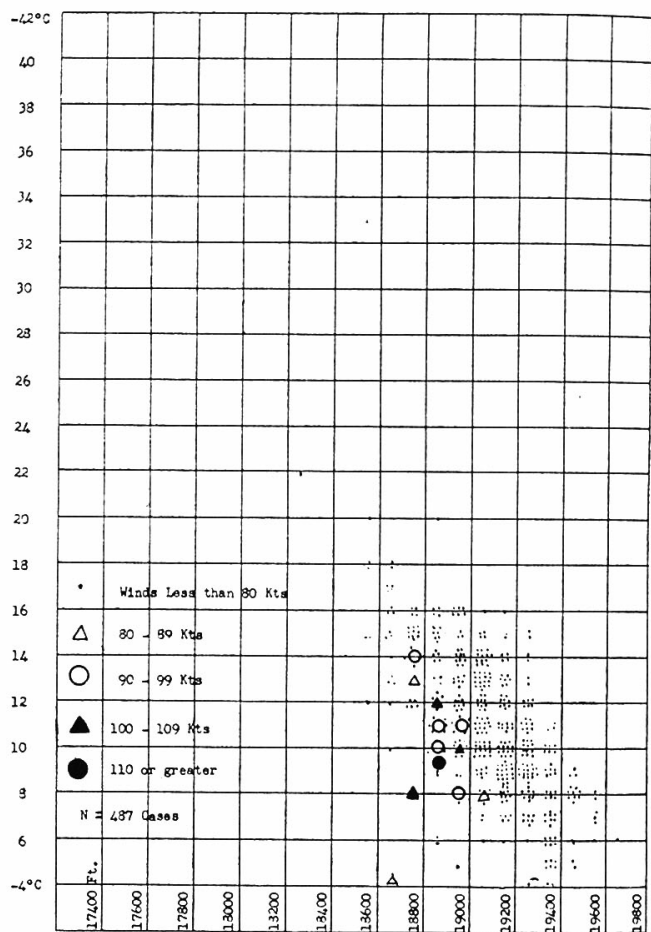

Fig. 14-Distribution of Velocities, Temperatures and $500 \mathrm{mb}$ Heights at Midway Island (066) $\left(28^{\circ} \mathrm{N} 177^{\circ} \mathrm{W}\right)$ during 20 Winter Months.

tures. The incidence of strong winds at $500 \mathrm{mbs}$ is not high, however, and markedly less than at OSV Victor upstream, even though both stations are located near the same latitude $\left(30^{\circ} \mathrm{N}\right)$. This suggests that, in general, the Jet Stream is less intense at $500 \mathrm{mbs}$ at this station or recurves northward prior to the longitude of Midway. Synoptically, the Polar Jet Stream is present over Midway rather infrequently; generally, it is north of the station.

While the greatest incidence of velocities below 80 knots occur in the range 19,000 to 19,200 feet there is strong shift towards moderate to strong velocities in the range 18,700 to 19,000 feet. In both instances the temperature range from $-8^{\circ} \mathrm{C}$ to $-14^{\circ} \mathrm{C}$ (Polar Front). Note the absence of strong wind velocities in association with cold temperatures.

Fig. $15-O S V$ Peter $\left(50^{\circ} \mathrm{N}-145^{\circ} \mathrm{W}\right)$ : Sample-144 cases ( 9 winter months). The distrib velocit by ter height. groups to -17 18,600 peratu Polar similar Tateno pear w althou found range. oscillat found of cold velocit In su the $\mathrm{Pac}$ cluster 


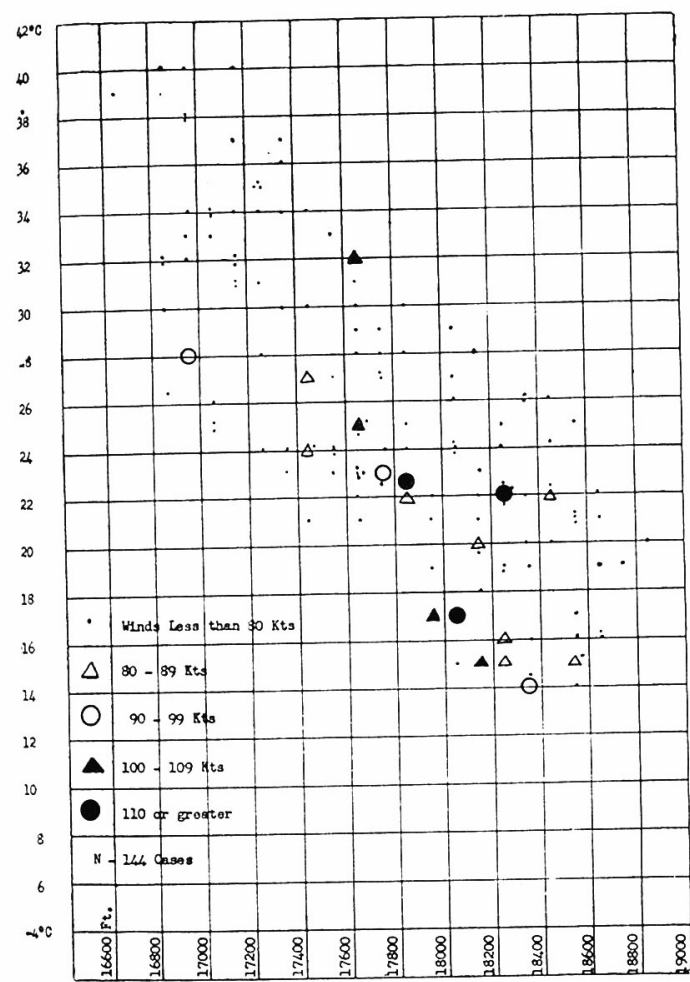

Fig. 15-Distribution of Velccities, Temperatures and $500 \mathrm{mb}$ Heights at OSV Peter $\left(50^{\circ} \mathrm{N}\right.$ $145^{\circ} \mathrm{W}$ ) during 9 Winter Months.

ds at kedly even r the that, tense urves Midtream ntly; and contour height groupings at the $500 \mathrm{mb}$ level ; namely :

a) $-27^{\circ} \mathrm{C}$ to $-37^{\circ} \mathrm{C}$ in the northerly latitudes of the Western Pacific. This thermal range is characteristic of those normally associated with the warm side of the Arctic Front. The contour height range is 17,000 to 17,800 feet.

b) $-16^{\circ} \mathrm{C}$ to $-27^{\circ} \mathrm{C}$ in the mid-latitudes of the Pacific with a tendency for a subdivision into the ranges $-16^{\circ} \mathrm{C}$ to $-23^{\circ} \mathrm{C}$ and $-24^{\circ} \mathrm{C}$ to $-27^{\circ} \mathrm{C}$. The overall thermal range also corresponds in large part to that range usually assigned to the Inter-Polar or Maritime Arctic Front. The height range is from 17,000 to 18,600 feet.

c) $-9^{\circ} \mathrm{C}$ to $-16^{\circ} \mathrm{C}$ in the latitudes close to $30^{\circ} \mathrm{N}$. This thermal range is characteristic of the Polar Front in the Pacific. The contour range is from 18,400 feet to 19,000

The foregoing does not imply that onfy "strong" wind velocities will occur when these thermal and contour height parameters are met. Indeed weak wind velocities are reported throughout the entire range of conditions but when "strong" winds do occur they occur within the restricted ranges given above. These thermal ranges correspond quite closely to those values given by McIntyre and Lee (4) who state-" The regions, relative to the $500 \mathrm{mb}$ temperature field, in which Jet Streams were most frequently found in January 1953 were as follows: from $-28^{\circ} \mathrm{C}$ to $-36^{\circ} \mathrm{C}$ at 18,000 to 50,000 feet; from $-20^{\circ} \mathrm{C}$ to $-28^{\circ} \mathrm{C}$ at 27,000 to 50,000 feet; $-15^{\circ} \mathrm{C}$ to $-20^{\circ} \mathrm{C}$ at 32,000 to 50,000 feet; from $-6^{\circ} \mathrm{C}$ to $-15^{\circ} \mathrm{C}$ at 30,000 to 45,000 feet."

\section{Conclusions}

a) During the winter each principal frontal zone has associated with it a well defined Jet Stream at altitudes above 20,000 feet. Since these Jet Streams are closely associated with frontal activity they can be identified with certain specific thermal regimes and contour heights characteristic 
of these frontal zones. In the Pacific Ocean area three principal frontal zones are dominant:

1) The Arctic Front with the Jet Stream being associated with the thermal range $-27^{\circ} \mathrm{C}$ to $-37^{\circ} \mathrm{C}$ and contour heights 17,000 feet to 17,800 feet at the $500 \mathrm{mb}$ level.

2) The Inter-Polar or Maritime Arctic Front-with the Jet Stream being associated with the thermal range $-16^{\circ} \mathrm{C}$ to $-27^{\circ} \mathrm{C}$ and contour heights 17,000 to 18, 600 feet at the $500 \mathrm{mb}$ level.

3) The Polar Front-with the Jet Stream being associated with the thermal range $-9^{\circ} \mathrm{C}$ to $-16^{\circ} \mathrm{C}$ and contour heights 18,400 feet to 19,000 feet at the $500 \mathrm{mb}$ level. b) The thermal and contour height regimes associated with the respective Jet Streams are quasi-conservative in time for each altitude and consequently, can be utilized as aids in aeronautical forecasting and navigation. Usually the frontal zones and their respective Jet Stream are sufficiently separate that the delineation of each is quite clear; however, in the region of well-defined long wave troughs there may be a merger of two Jet Streams to from one well-defined broad band of intense wind speeds. The thermal complex associated with this merger will encompass the thermal regimes characteristic of each individual Jet Stream but their individual delineation is often hampered by lack of an adequately dense network of data in the area.

\section{References}

1) Anderson, R., B. W. Boville and D. E. McClellan, 1955 : An operational frontal contouranalysis mode1. Quart. J. r. meteor. Soc., 81, No. 350, pp 588-599 -2) Godson, M. L., 1950: The structure of northrn American weather systems. Centenary Proc. roy. meteor. Soc., pp. 89-106 -3) McIntyre, D. P., 1950: On the air-mass temperature distribution in middle and high troposphere in winter. J. Meteor. 7. pp. 101-107. -4) McIntyre, D. P. and R. Lee, 1954: Jet streams in middle and high latitudes. Proc. Toronto Meteox. Conf. 1953, pp 172-181 -5) Penner, C. M., 1955: A three front model for synoptic analysis. Quart. J. r. meteor. Soc., 81, No. 347. pp. 89-91 -6) Serebreny, S. M., 1955: The jet stream structure over the Pacific. J. Inst. Nav., 4, No. 6, pp. 231 241. -7) Serebreny, S. M., E. J. Wiegman and W. F., Carlson, 1955: Characteristic properties of the jet stream over the Pacific Tech. Rep. No. 1, 2, 3, 4, Pan American World Airways, Metecrology Section, San Francisco, California. (Prepared under contract with project Arowa, BuAer, U. S. Navy) -8) Serebreny, S. M., E. J., Wiegman, W. F., Carlson and J. G. Cronin, 1953 : Forecasting manual for the jet stream over the Pacific. Pan American world Airways, Meteorological Section, San Francisco. California. Navaer 50-1 P-536. (Prepared under contract with Project Arowa. BuAer, U. S. Navy) -9) Tables of Winds and their Aiding and Retarding Effect, 850, 700, 500, 300 and $200 \mathrm{mb}$, Part I, North Pacific Area. 1944: U. S. Navy, Navaer 50-1c-526 